\title{
PENGARUH PERAWATAN PAYUDARA TERHADAP \\ PRODUKSI ASI DI RSU SAWERIGADING \\ KOTA PALOPO
}

\author{
Arifa Usman \\ Arifa.cube@gmail.com
}

\begin{abstract}
ABSTRAK
Latar belakang: ASI adalah suatu emulsi lemak dalam larutan protein, laktose dan garam-garam organik yang disekresi oleh kedua belah kelenjar payudara ibu, sebagai makanan utama bagi bayi. ASI merupakan nutrisi alamiah terbaik bagi bayi karena mengandung kebutuhan energi dan zat yang dibutuhkan selama enam bulan pertama kehidupan bayi. Tujuan: untuk mengetahui pengaruh perawatan payudara terhadap produksi ASI di RSU Sawerigading Kota Palopo Tahun 2017. Metode: penelitian ini menggunakan metode Quasi-Eksperiment dengan pendekatan Non-Equivalen Control Group atau non-rondomized control group pretest-postest design. Populasi dalam penelitian ini adalah semua ibu nifas yang dirawat di RSU Sawerigading Kota Palopo tahun 2017 sebanyak 40 orang. Sampel dalam penelitian ini sejumlah 40 orang dengan teknik pengambilan sampel Accidental sampling. Pengumpulan data melalui data primer (lembar observasi) dan data sekunder. Data diolah menggunakan Statistical Product and Service Solution (SPSS) 21 dan dianalisis secara univariat dan bivariat dengan uji statistik Mann-Whitney Test serta disajikan dalam bentuk tabel distribusi frekuensi. Hasil: ada pengaruh perawatan payudara terhadap produksi ASI ( $P$-Value $=.001<0.05)$. Kesimpulan: ada pengaruh perawatan payudara terhadap produksi ASI di RSU Sawerigading Kota Palopo.
\end{abstract}

Kata Kunci : Produksi ASI, Perawatan Payudara 


\section{PENDAHULUAN}

Air Susu Ibu (ASI) adalah hadiah terindah dari ibu kepada bayi yang disekresikan oleh dua belah kelenjar payudara ibu berupa makanan alamiah atau susu terbaik bernutrisi dan berenergi tinggi yang mudah dicerna dan mengandung komposisi nutrisi yang seimbang dan sempurna untuk tumbuh kembang bayi yang tersedia setiap saat, siap disajikan dalam suhu kamar dan bebas dari kontaminasi. ASI juga mengandung beberapa mikronutrien yang dapat membantu memperkuat daya tahan tubuh bayi. Selain itu, pemberian ASI minimal selama 6 bulan juga dapat menghindarkan bayi dari obesitas atau kelebihan berat badan karena ASI membantu menstabilkan pertumbuhan lemak bayi. (Wiji, 2013)

\section{World Health Organization /}

\section{United Nations Children's Fund} (WHO/UNICEF) mengemukakan standar emas pemberian makan pada bayi dan anak adalah 1) mulai segera menyusui dalam 1 jam setelah lahir 2) menyusui bayi secara eksklusif sejak lahir sampai dengan umur 6 bulan, dan 3) mulai umur 6 bulan bayi mendapat Makanan Pendamping ASI (MP-ASI) yang bergizi sesuai dengan kebutuhan tumbuh kembangnya dan 4) meneruskan menyusui anak sampai umur 24 bulan atau lebih. ASI Eksklusif memiliki kontribusi yang besar terhadap tumbuh kembang dan daya tahan tubuh anak. Anak yang diberi ASI Eksklusif akan tumbuh dan berkembang secara optimal dan tidak mudah sakit. Hal tersebut sesuai dengan beberapa kajian dan fakta global.

Kajian global "The Lancet Braestfeeding Series" 2016 telah membuktikan 1) Menyusui Eksklusif menurunkan angka kematian karena infeksi sebanyak $88 \%$ pada bayi berusia kurang dari 3 bulan, 2) Sebanyak $31.36 \%$ (82\%) dari $37.94 \%$ anak sakit, karena tidak menerima ASI Ekslusif. Investasi dalam pencegahan BBLR, Stunting dan meningkatkan Inisiasi Menyusu Dini (IMD) dan ASI Eksklusif berkontribusi dalam menurunkan risiko obesitas dan penyakit kronis (Patal, 2013). Tidak menyusui berhubungan dengan kehilangan nilai ekonomi sekitar \$302 milyar setiap tahunnya atau sebesar $0-49 \%$ dari Pendapatan Nasional Broto (Lancet, 2016).

Pemberian ASI Eksklusif masih belum seperti yang diharapkan, menurut hasil Survei Demografi dan Kesehatan Indonesia (SDKI) tahun 2012, bayi usia 
4-5 bulan yang mendapatkan ASI eksklusif sebesar 27\%, sedangkan sebesar $7.9 \%$ bayi diberi susu lain dan sebesar $7.9 \%$ diberi air putih. Persentase pemberian susu lain menurut usia bayi adalah sebesar $31.5 \%$ pada usia 0-1 bulan, $18 \%$ pada bayi usia 2-3 bulan, dan $7.9 \%$ pada bayi usia 4-5 bulan. Berdasarkan penelitian di Kota Ambon tahun 2013, diketahui jika responden yang memberikan PASI kepada bayi usia 0-6 bulan berupa susu formula sebesar $\quad 80.49 \%$. UNICEF mengungkapkan bukti ilmiah bahwa bayi yang diberikan susu formula memiliki kemungkinan untuk meninggal dunia pada bulan pertama kelahirannya. Peluang tersebut meningkat 25 kali tinggi dibandingkan bayi yang disusui oleh ibunya secara eksklusif. (Ida Nurmawati et al, 2015)

Mengacu pada target Rencana Strategis (Renstra) pada tahun 2015 yang sebesar $39 \%$, maka secara nasional cakupan pemberian ASI eksklusif pada bayi usia kurang dari enam bulan sebesar $55.7 \%$ telah mencapai target. Menurut provinsi, kisaran cakupan ASI eksklusif pada bayi umur 0-6 bulan antara $26.3 \%$ (Sulawesi Utara) sampai 86.9\% (Nusa Tenggara Barat). Dari 33 provinsi yang melapor, sebanyak 29 diantaranya $(88 \%)$ berhasil mencapai target Renstra 2015. (Ditjen Kesehatan Masyarakat, Kemenkes RI, 2016)

Berdasarkan data yang diperoleh dari Dinas Kesehatan Provinsi Sulawesi Selatan Tahun 2015, cakupan pemberian ASI eksklusif pada bayi umur 0-6 bulan sebanyak 71.5\%. (Data Sekunder Dinas Kesehatan Provinsi Sulawesi Selatan)

Menurut data yang diperoleh dari Dinas Kesehatan Kota Palopo, cakupan pemberian ASI eksklusif pada bayi umur 0-6 bulan pada tahun 2015 sebanyak 790 bayi (67.04\%) dan tahun 2016 sebanyak 533 bayi (67.82\%). (Data Sekunder Dinas Kesehatan Kota Palopo)

Data yang diperoleh dari Rekam Medik RSU Sawerigading Kota Palopo, ibu postpartum dengan persalinan normal pada tahun 2014 sebanyak 542 orang dan persalinan dengan Sectio Caesarea sebanyak 832 orang, tahun 2015 sebanyak 606 orang persalinan normal dan persalinan dengan Sectio Caesarea sebanyak 832 orang, tahun 2016 sebanyak 699 orang persalinan normal dan persalinan dengan Sectio Caesarea sebanyak 958 orang, dan 
tahun 2017 bulan januari sampai dengan bulan februari sebanyak 80 orang persalinan normal dan persalinan dengan Sectio Caesarea sebanyak 125 orang. (Data Sekunder RSU Sawerigading Kota Palopo)

Berdasarkan hasil penelitian sebelumnya yang dilakukan oleh $\mathrm{R}$. Pranaja dan Novita Rudiyanti (2013), Hasil analisis diperoleh bahwa terdapat $41.1 \%$ (23) responden yang melakukan perawatan payudara mempunyai produksi ASI cukup dan 67.9\% (95) responden yang tidak melakukan perawatan payudara mempunyai produksi ASI cukup. Hasil uji statistik diperoleh nilai $P$-Value $=.001$, disimpulkan secara statistik ada hubungan yang signifikan antara perawatan payudara dengan produksi ASI.

\section{METODE PENELITIAN}

\section{Desain Penelitian}

Desain penelitian yang digunakan dalam penelitian ini adalah penelitian survey analitik menggunakan metode kuantitatif dengan desain cross sectional. Variabel independen yang terdiri dari keturunan, multiparitas dan diabetes mellitus yang diukur secara bersama-sama dalam waktu yang sama dengan variabel dependennya yaitu kejadian makrosomia dimana subjek dalam penelitian ini adalah ibu bersalin yang melahirkan bayi dengan berat badan bayi >4000 gram di Rumah Sakit Sawerigading Palopo

\section{Populasi dan Sampel}

1. Populasi

Populasi dalam penelitian ini adalah semua ibu bersalin yang melahirkan bayi dengan berat badan bayi $>4000$ gram yang tercatat di buku register Rumah Sakit Sawerigading Kota Palopo

2. Sampel

Sampel dalam penelitian ini adalah ibu bersalin yang melahirkan bayi dengan berat badan bayi $>4000$ gram keseluruhan dari jumlah populasi yaitu 30 responden. Tehnik pengambilan sampel pada penelitian ini adalah dengan menggunakan tehnik total sampling yaitu seluruh populasi dalam penelitian.

\section{Metode Pengumpulan Data}

Metode pengumpulan yang dilakukan dengan menggunakan dua tehnik yaitu :

1. Data primer disebut juga data tangan pertama. Dalam penelitian ini data 
primer di dapatkan dari responden atau klien.

2. Data sekunder disebut juga data tangan kedua. dalam penelitian ini data sekunder di dapatkan dari rekam medik, buku pencatatan ruang Perinataogi rumah sakit Sawerigading Palopo.

Sebelum melakukan pengumpulan data terlebih dahulu peneliti meminta izin kepada Direktur Rumah Sakit Sawerigading Kota Palopo untuk melakukan penelitian di rumah sakit tersebut. Lembar observasi yang telah di isi, kemudian dikumpulkan dan dicek oleh peneliti untuk diolah dan dianalisis.

\section{HASIL PENELITIAN}

\section{Analisis Univariat}

Penelitian ini dilaksanakan pada bulan Juni-Juli 2017 dengan membagikan lembar observasi kepada ibu bersalin yang melahirkan bayi dengan berat badan bayi >4000 gram di RSUD Sawerigading Palopo tahun 2017 dengan jumlah sampel 16 responden. Penelitian ini bertujuan untuk mengetahui faktor yang berhubungan dengan kejadian makrosomia di Rumah Sakit Sawerigading Palopo menunjukan bahwa dari 16 responden, terdapat kelompok ibu bersalin yang melahirkan bayi dengan berat badan bayi > 4000 gram berjumlah 9 ibu bersalin (56,2\%), dan kelompok ibu bersalin yang melahirkan bayi dengan berat badan bayi $\leq 4000$ gram yang berjumlah $7 \mathrm{ibu}$ bersalin $(43,8 \%)$.

menunjukkan bahwa dari 16 responden, kelompok ibu terdiagnosa memiliki riwayat penyakit diabetes melitus yang berjumlah 5 ibu bersalin $(31,2 \%)$, dan kelompok ibu tidak terdiagnosa memiliki riwayat penyakit diabetes melitus berjumlah 11 ibu bersalin $(68,8 \%)$.

menunjukkan bahwa dari 16 responden, kelompok ibu bersalin yang pada saat hamil mengalami kenaikan berat badan $\geq 15 \mathrm{~kg}$ yang termasuk resiko tinggi berjumlah 5 ibu bersalin $(31,2 \%)$ dan kelompok ibu bersalin yang pada saat hamil mengalami kenaikan berat badan $<15 \mathrm{~kg}$ yang termasuk resiko rendah 11 ibu bersalin $(68,8 \%)$

Menunjukkan bahwa dari 16 responden, ibu yang punya riyawat melahirkan bayi makrosomia dan multipara yang termasuk resiko tinggi berjumlah $6 \mathrm{ibu}$ 
bersalin $(37,5 \%)$, dan ibu yang tidak ada riwayat melahirkan bayi makrosomia yang termasuk resiko rendah berjumlah 10 ibu bersalin $(62,5 \%)$.

\section{Analisis Bivariat}

Pengaruh Perawatan Payudara

Terhadap Produksi ASI Pada Ibu

Nifas di RSU Sawerigading Kota

Palopo Tahun 2017

\begin{tabular}{|c|c|c|c|c|c|}
\hline \multirow{3}{*}{$\begin{array}{l}\text { Produksi } \\
\text { ASI }\end{array}$} & \multicolumn{5}{|c|}{ Perawatan Payudara } \\
\hline & \multicolumn{2}{|c|}{ Eksperimen } & & Kontro & \multirow[t]{2}{*}{ P-Value } \\
\hline & $\mathrm{N}$ & $\%$ & $\mathrm{~N}$ & $\%$ & \\
\hline Baik & 20 & 100 & 12 & 60 & \\
\hline Kurang & 0 & 0 & 8 & 40 & .001 \\
\hline Total & 20 & 100 & 20 & 100 & \\
\hline
\end{tabular}

menunjukkan bahwa dari 40 sampel, terdapat produksi ASI dalam kurun waktu 4 hari sebanyak 20 (100\%) orang pada kelompok eksperimen (perlakuan), terdapat $12(60 \%)$ orang pada kelompok kontrol. Sedangkan produksi ASI yang tidak tepat waktunya (>4 hari) tidak terdapat pada kelompok eksperimen (perlakuan) dan terdapat 8 (40\%) orang pada kelompok kontrol.

Berdasarkan hasil uji statistik dengan menggunakan uji MannWhitney Test didapatkan nilai kemaknaan $P$-Value $=.001$ lebih kecil dari nilai $\alpha$ (0.05). Dapat diambil kesimpulan bahwa Ho ditolak dan $\mathrm{Ha}$ diterima yang berarti ada pengaruh perawatan payudara terhadap produksi ASI pada ibu nifas.

\section{PEMBAHASAN}

Berdasarkan Analisis Bivariat produksi ASI dalam kurun waktu 4 hari terdapat $20(100 \%)$ orang pada kelompok eksperimen (perlakuan) dan terdapat $12(60 \%)$ orang pada kelompok kontrol. Sedangkan produksi ASI yang tidak tepat waktunya (>4 hari) tidak terdapat pada kelompok eksperimen (perlakuan) dan terdapat $8(40 \%)$ orang pada kelompok kontrol.

$$
\text { Pada hasil uji statistik secara }
$$
komputerisasi dengan menggunakan uji Mann-Whitney Test didapatkan nilai kemaknaan P-Value sebesar .001 maka dapat disimpulkan bahwa $001<0.05$. Dari kesimpulan tersebut dapat diambil keputusan Ho ditolak dan Ha diterima yang berarti ada pengaruh perawatan payudara terhadap produksi ASI pada ibu nifas.

Berdasarkan hasil wawancara yang telah dilakukan kepada bidan yang bertugas di ruang nifas RSU 
Sawerigading Kota Palopo, diperoleh bahwa perawatan payudara dilakukan dan pelaksanaannya dilakukan pada hari kedua setelah melahirkan. Hasil yang diperoleh melalui wawancara kepada ibu nifas bahwa setelah melakukan perawatan payudara, terdapat ibu nifas yang mengalami pengeluaran ASI namun belum terlalu banyak.

Pemberian ASI Eksklusif masih belum seperti yang diharapkan, menurut hasil Survei Demografi dan Kesehatan Indonesia (SDKI) tahun 2012, bayi usia 4-5 bulan yang mendapatkan ASI eksklusif sebesar 27\%, sedangkan sebesar $7.9 \%$ bayi diberi susu lain dan sebesar $7.9 \%$ diberi air putih. Persentase pemberian susu lain menurut usia bayi adalah sebesar $31.5 \%$ pada usia 0-1 bulan, 18\% pada bayi usia 2-3 bulan, dan $7.9 \%$ pada bayi usia 4-5 bulan. Berdasarkan penelitian di Kota Ambon tahun 2013, diketahui jika responden yang memberikan PASI kepada bayi usia 0-6 bulan berupa susu formula sebesar $\quad 80.49 \%$. UNICEF mengungkapkan bukti ilmiah bahwa bayi yang diberikan susu formula memiliki kemungkinan untuk meninggal dunia pada bulan pertama kelahirannya. Peluang tersebut meningkat 25 kali tinggi dibandingkan bayi yang disusui oleh ibunya secara eksklusif. (Ida Nurmawati et al, 2015) Mengacu pada target Rencana Strategis (Renstra) pada tahun 2015 yang sebesar 39\%, maka secara nasional cakupan pemberian ASI eksklusif pada bayi usia kurang dari enam bulan sebesar $55.7 \%$ telah mencapai target. Menurut provinsi, kisaran cakupan ASI eksklusif pada bayi umur 0-6 bulan antara 26.3\% (Sulawesi Utara) sampai 86.9\% (Nusa Tenggara Barat). Dari 33 provinsi yang melapor, sebanyak 29 diantaranya $(88 \%)$ berhasil mencapai target Renstra 2015. (Ditjen Kesehatan Masyarakat, Kemenkes RI, 2016)

Berdasarkan asumsi peneliti, dapat dilihat bahwa terdapat perbandingan yang jauh antara produksi ASI yang diberikan perlakuan perawatan payudara secara teratur dan benar akan menghasilkan produksi

ASI lancar. Hal ini dapat meningkatkan kasih sayang antara ibu dan bayi serta kebutuhan bayi akan terpenuhi. Pada ibu nifas sebaiknya melakukan perawatan payudara secara teratur karena selain untuk memelihara kebersihan putting, 
perawatan payudara juga dapat denganumur.

memperlancar produksi ASI. Langkahlangkah dalam melakukan perawatan payudara hendaknya dilakukan secara berurutan. Pada ketidaklancaran produksi ASI yang terjadi tersebut dapat diketahui dari tanda-tanda ASI yang tidak lancar, seperti : ASI tidak dapat keluar secara spontan dan memerlukan alat bantu, sebelum disusukan payudara terasa lembek, bayi kencing kurang dari 8 kali per hari, dan berat bayi tidak mengalami kenaikan yang sesuai

\section{KESIMPULAN}

Setelah dilakukan penelitian, pengolahan data dan pembahasan tentang pengaruh perawatan payudara terhadap produksi ASI pada ibu nifas di RSU Sawerigading Kota Palopo yaitu pengaruh perawatan payudara terhadap produksi ASI pada ibu nifas di RSU Sawerigading Kota Palopo 


\section{DAFTAR PUSTAKA}

Ahonen, J., Stevanovic, V. \& Lassila, R. (2010) Management of post-partum haemorrhage. Acta Anaesthesiologica Scandinavica, 54(10): 1164-1178

BPS \& Macro International (2007) Survei Demografi dan Kesehatan Indonesia.Calverton, Maryland: Macro International.

Cunningham, F. G. et. Al, 2006 Obstetri Williams, EGC : Jakarta

Fibriana, A. I, (2010) three delay model sebagai salah satu determinan kematian ibu Di kabupaten cilacap, Tesis, Universitas Negeri Semarang

Gunantoro (2002) Faktor-faktor yang berhubungan dengan pemilihan penolong persalinan di kecamatan cibadak kabupaten Bogor Tahun 2002, Fakultas Kesehatan Masyarakat Universitas Indonesia

Lubis, I. K. (2011) Pengaruh Paritas terhadap Perdarahan Postpartum Primerdi RSUD dr.Pirngadi Medan 2011, Universitas Sumatera Utara

Mochtar, R (2002) Sinopsis Obstetri. Jakarta : EGC

Menkes RI (2008) Keputusan Menteri Kesehatan Republik Indonesia Nomor:1051/MENKES/SK/XI/2008 Tentang Pedoman Penyelenggaraan Pelayanan Obstetri Neonatal Emergensi Komprehensif(Ponek) 24 Jam diRumah Sakit, Jakarta:Kemeterian Kesehatan RI. 
Pattianakotta, L. A. (2012) Faktor-faktor yang berhubungan dengan rujukan kasus kegawatdaruratan obstetric neonatal oleh bidan desa ke puskesmas PONED di kabupaten Maluku Tengah, Universitas Indonesia

Ritonga, N. A. (2007) Manajemen Unit Gawat Darurat pada Penanganan Kasus Kegawatdaruratan Obstetri di Rumah Sakit Umum Tengku Mansyur Tanjung Balai, Tesis, Universitas Gadjah Mada

Saifudin, A. B., Wiknjosasastro, G. H., Affandi, B. \& Waspodo, D. (2007) Buku Panduan Praktis Pelayanan Kesehatan Maternal dan Neonatal, Jakarta:JNPKKRPOGI-JHPIEGO/MNH \& Yayasan Bina Pustaka Sarwono Prawirohardjo.

Shane, B. (2001) Preventing postpartum hemorrhage: managing the third stage oflabor. Outlook (Maternal and Neonatal Health Special Issue): Seattle.PATH, 19(3): 1-8.

Shane, B. (2002) Mencegah perdarahan paska persalinan: Menangani persalinankala tiga. Outlook, 19.

Wilde, E. T.(2009). Do Emergency Medical System Response Times Matter for Health Outcomes?. New York: Columbia University

Yoon, P., Steiner, I., Reinhardt, G.(2003). Analysis of factos influencing length of stay in the emergency departments, (Online). 